\title{
The Relationship Between Test Anxiety and Academic Self - Regulated Learning Among Foundation Students in lium
}

\author{
Hammood Msayar, Radin Akhmal, Radin Mardhiana \\ Department of Educational Psychology, International Islamic University Malaysia, Gombak, Selangor, Malaysia \\ Email address: \\ Hamooda740@gmail.com (H. Msayar), akmaleyzad@gmail.com (R. Akhmal)

\section{To cite this article:} \\ Hammood Msayar, Radin Akhmal, Radin Mardhiana. The Relationship Between Test Anxiety and Academic Self - Regulated Learning \\ Among Foundation Students in Iium. Science Journal of Education. Vol. 4, No. 2, 2016, pp. 39-45. doi: 10.11648/j.sjedu.20160402.14
}

Received: February 25, 2016; Accepted: March 22, 2016; Published: March 25, 2016

\begin{abstract}
Educational institutions rely on the exams to assess the knowledge level of the students in the various stages of education that allows students to move to a new phase academy and get academic certificate they want. It has become the tests constitute an obstacle in the way of students to realize their dreams of getting a decent job dependent at the academic achievements, especially the final exams because the questions are the comprehensive curriculum. This study can help them to overcome their anxiety during examinations, so that they can perform better and achieve good grades. The current research revealed that most of the students had high level of test anxiety and academic self-regulated. There was no statistically significant difference between male and female in their test anxiety also the result showed that there was a statistically significant difference between male and female in their academic self-regulated Pearson's regression showed that self regulated did not predict test anxiety.
\end{abstract}

Keywords: Test Anxiety, Academic Self-Regulated Learning, Foundation Students

\section{Introduction}

Educational institutions rely on the exams to assess the knowledge level of the students in the various stages of education that allows students to move to a new phase academy and get academic certificate they want. It has become the tests constitute an obstacle in the way of students to realize their dreams of getting a decent job dependent at the academic achievements, especially the final exams because the questions are the comprehensive curriculum. From the previous, students start to think about how they will pass of these tests, so they have anxiety and fear of the result of the exam. As a result, the concept of test anxiety, a psychological condition emotional temporary passes by the student, and accompanied by reactions of psychological and physical result of the expected failure in the exam or bad performance in it, or fear of the negative reactions of the parents.

Test anxiety defined as the set of phenomenological, physiological and behavioral responses that accompany concern about possible negative consequences or failure on an exam or similar evaluative situation [2]. The term generally refers to the set of phenomenological, physiological, and behavioral responses that accompany concern about possible negative consequences or failure on exam or similar evaluative situation. The transactional model of test anxiety developed by Charles Spielberg \& Peter Vagg (1995), as cited in Cizek \& Burg (2006, p.18), assumes that the test anxiety process begins with the student 's perception of the task. This perception is influenced by the degree of the student's mastery of study skills. In other words, the level of test anxiety was found to be correlated with the level of mastery of study skills.

One of the study strategies that can be applied in seeking knowledge is self- regulated learning strategy. Self-regulated learning is a strategy which can be defined as the use of metacognitive, motivational, and behavioral processes in the learning process [26]. The Commission of the European Community (2000) as cited in Wirth \& Leutner (2008) regards competence in self-regulated learning as a necessary prerequisite for lifelong learning.

Similarly, a review done by Mohamed Abdirahman Maalim (2004) found that Self-regulated learning is considered to be a vital prerequisite for successful learning in all-educational settings, and models of self-regulated learning provide a very useful description of what effective learners 
do in their school subjects or college course. For instance, several previous studies have demonstrated the efficacy of self-regulated learning. Self-regulated learning was correlated with positive effects in academic achievement [3]. The study examined the relationship between test anxiety and academic self-regulated learning an $\mathrm{d}$ the differences between genders.

\subsection{Statement of Problem}

It might be difficult for students to maintain a consistently high level of achievement in the face of persistent test anxiety, because it inhibits peak performance [2]. Davies (1986) explained that anxiety can disrupts and disorganizes behavior through a lowering of attention, concentration, and intellectual control, as the consequence, students who measure high in test anxiety are usually found to be poor performers in tests and examinations, compared to those with low anxiety levels [32]. In addition, test anxiety was also found to be negatively correlated with self-efficacy that can lead to experience sense of helplessness [31]. It is, therefore, imperative to seek that can decrease the students' level of test anxiety. In conclusion, test anxiety influential factor in the low performance of students in the exam.

\subsection{Purpose of the Study}

The aim of this study is to investigate the level of test anxiety as well as the level of academic self-regulated learning. This study also wants to investigate if there is any significant relationship between test anxiety and academic of self-regulated learning as well as to identify the differences between genders on the level of test anxiety and selfregulated learning.

1. What is the level of test anxiety among foundation students?

2. What is the level of academic self-regulated learning among foundation students?

3. Is there any significant relationship between test anxiety and academic of self-regulated learning?

4. Are there any differences between gender in the level of test anxiety and self-regulated learning?

\section{Literature Review}

\subsection{Test Anxiety}

Educational tests are the major medium for measuring academic achievement. Although varying methods of evaluation are used in educational settings, tests will remain the most commonly used method of assessment. Nonetheless, a number of external psychological and social factors may have substantial effects on performance on these powerful assessment tools. Several terms have been coined to account for these significant effects on test performance. One of these terms is 'test anxiety', a condition that involves excessive worry in testing situations. The concept of test anxiety was first identified as a psychological phenomenon in the 1930s by Luria, Brown, and Neumann (Burn, 2004), and later developed and operationalized by Mandler and Sarason (1952). Since then, the construct has been "closely studied and has grown as an area of educational research" [10].

The Anxiety Disorder Association of America (ADAA) identified a variety of variables that cause test anxiety to include: Anxiety, attention or obsessive compulsive disorders, perfectionist tendencies and unrealistic expectations, negative self-esteem, self-statements and criticism, poor motivation, lack of confidence and procrastination, inadequate study and test taking skills, poor prior testing performance, Pressure from peers, family and teacher, unfavorable testing environments, invalid flawed and timed tests, ineffective teaching and reducing test anxiety.

\section{Test Anxiety and Genders}

Several studies reported significant differences on levels of test anxiety between gender groups. The studies reported female students to be more test-anxious than the males. In 2008, Putwain examined the effect of gender and socioeconomic background on test anxiety, and the performance in the General Certificate of Secondary Education (GCSE). The test anxiety levels of 557 secondary school students in the UK were assessed through the Spielberger's Test Anxiety Inventory (1980). This study reported that there is a significant effect of gender on test anxiety total score, worry, and emotionality.

Cassady and Johnson (2002) examined gender differences in test anxiety between 114 females and 53 male undergraduate educational psychology students at a large Midwestern university. In order to assess students' level of test anxiety, they developed the Cognitive Test Anxiety Scale. The result of the study demonstrated that females reported higher levels of both emotionality and cognitive test anxiety than males.

\subsection{Academic of Self-Regulated Learning}

Self-regulated learning can be defined as a learning process involving active metacognition, motivation, and behavior [26]. In terms of metacognitive processes, selfregulated learning uses planning, organization, selfinstruction, and self-evaluation at various stages during the acquisition process. In terms of motivation, there is a perception of becoming self- efficacious, autonomous, and intrinsically motivated in learning. In terms of behavior, selfregulated learning requires the optimizing of the acquisition through selecting, structuring, and creating supportive environments.

Zimmerman and Martinez-Pons (1988) validated a model of self-regulated learning strategies. The model comprises 14 constructs; self-evaluation, organizing and transforming, goal setting and planning, seeking information, keeping records and monitoring, environmental structuring, self-consequence, rehearsing and memorizing, seeking peer assistance, seeking teacher assistance, seeking adult (non teacher) assistance, reviewing tests, reviewing notes, and reviewing texts. Further, they created an instrument, namely Self-Regulated Learning Interview Schedule (SRLIS), to assess the use of these strategies in six different learning contexts; in classroom 
situations, when studying at home, when completing writing assignments, when preparing for and taking tests, and when poorly motivated to complete homework. In addition, to know teachers' rating on students' use of SRL strategies in the classroom setting, they created the Rating Student SelfRegulated Learning Outcomes: A Teacher Scale (RSSRL).

Adopting from Zimmerman and Martinez-Pons's (1988) model of self- regulated learning, Magno (2010) derived the new model consisting of seven factors highlighting the use of self-regulated learning in the academic setting. The first six factors, namely goal-setting, memory strategy, selfevaluation, seeking assistance, environmental structuring, and organizing were extracted from Zimmerman and Martinez-Pons 's (1988) framework without isolating the components of seeking information, keeping records, and reviewing as separate factors, considering that theses specific skills are all used in other learning strategies such as organizing, setting goals, environmental structuring, and memory strategy. Besides, Magno (2010) emerged a new factor, namely responsibility.

Magno (2010) justified the emergent factor - responsibility - as part of the use of SRL. First, Zimmerman and Kitsantas's (2005) perceived the responsibility scale together with the items reflecting self-regulated learning as being valid and reliable indices. Second, Zimmerman and Martinez-Pons (1988) found that perceived responsibility was significantly correlated with the Rating Student SelfRegulated Learning Outcomes: A Teacher Scale (RSSRL). Therefore, Magno's (2010) model of self-regulated learning consists of seven factors, which are goal setting, memory strategy, self-evaluation, seeking assistance, environmental structuring, responsibility, and organizing.

\section{Method}

\subsection{Population and Sample}

The populations of this study 624 foundation student in Kulliyyah of Economic at International Islamic University with age between 18 to 20 years old. The researcher utilizes a purposive sampling to obtain the respondents who fulfilled the characteristics required for the research. The respondents consisted of 124 of foundation students in Kulliyyah of Economic in IIUM.

\subsection{Instrumentation}

For the purpose of addressing the research questions and the overall purpose of the study, the researcher uses the Academic Self-Regulated Learning Scale (A-SRL-S) developed by Carlo Magno (2010) and the Test Anxiety Inventory (TAI) developed by Charles D. Spielberger (1980).

\subsection{Reliability}

The alpha coefficients for the five normative samples (high school students, college freshman, community college students, college undergraduates, and naval personnel) ranged from .92 to .96 for the TAI total, from .83 to .91 for the TAI-Worry, and from .85 to .91 for the TAI- Emotionality. For the test-retest reliability, the coefficient of .80 to .81 were reported for a 2-week to 1-month period for groups of high school, college, and graduate students. For high school students, the reliability was .62 after six months. Each factor of the A-SRL-S showed a high internal consistency, ranging from (.73 to .87) (Magno, 2011). Magno (2010) reported the high internal consistency for both person $(.61-.81)$ and item responses $(.83-.99)$ through the Rasch analysis.

\subsection{Data Analysis Procedure}

The data obtained, were analyzed using the SPSS (Statistical Package for the Social Science) software. In analyzing the data, the researcher used descriptive statistics and several other statistical tools, including an Independent T-test, and the sample regression Test.

\section{Result}

\subsection{Level of Test Anxiety}

Table 4.1. Level of test anxiety among foundation students in the Kulliyyah of Economic.

\begin{tabular}{|c|c|c|c|c|}
\hline Item & 1 & 2 & 3 & 4 \\
\hline I wish examinations do not bother me so much. & 13 & 31 & 37 & 42 \\
\hline $\begin{array}{l}\text { I feel very jittery (nervous) when taking an } \\
\text { important test }\end{array}$ & 6 & 44 & 44 & 30 \\
\hline $\begin{array}{l}\text { Even when I 'm well prepared for a test, I feel } \\
\text { very nervous about it. }\end{array}$ & 8 & 49 & 45 & 22 \\
\hline $\begin{array}{l}\text { During examinations I get so nervous that I } \\
\text { forget facts I really know. }\end{array}$ & 12 & 56 & 38 & 18 \\
\hline $\begin{array}{l}\text { I start feeling very uneasy just before getting a } \\
\text { test paper back. }\end{array}$ & 13 & 42 & 53 & 16 \\
\hline $\begin{array}{l}\text { After an examination is over I try to stop } \\
\text { worrying about it, but I can't. }\end{array}$ & 23 & 55 & 30 & 16 \\
\hline I feel confident and relaxed while taking tests. & 9 & 63 & 39 & 13 \\
\hline $\begin{array}{l}\text { Thinking about my grade in a course interferes } \\
\text { with my work on tests. }\end{array}$ & 7 & 67 & 37 & 13 \\
\hline $\begin{array}{l}\text { While taking examinations I have an uneasy, } \\
\text { upset feeling. }\end{array}$ & 8 & 85 & 23 & 8 \\
\hline $\begin{array}{l}\text { I feel very panicky when I take an important } \\
\text { examination. }\end{array}$ & 23 & 47 & 41 & 13 \\
\hline $\begin{array}{l}\text { I worry a great deal before taking an important } \\
\text { examination }\end{array}$ & 17 & 55 & 39 & 13 \\
\hline $\begin{array}{l}\text { During tests I find myself thinking about the } \\
\text { consequences of failing. }\end{array}$ & 25 & 52 & 34 & 13 \\
\hline $\begin{array}{l}\text { During examinations I find myself thinking } \\
\text { about whether I 'll ever get through school } \\
\text { (graduate from the university). }\end{array}$ & 30 & 48 & 34 & 12 \\
\hline $\begin{array}{l}\text { I seem to defeat (to do something against } \\
\text { myself 'interest) myself while working on an } \\
\text { important test. }\end{array}$ & 27 & 56 & 30 & 11 \\
\hline $\begin{array}{l}\text { I feel my heart beating very fast during } \\
\text { important tests. }\end{array}$ & 22 & 47 & 44 & 11 \\
\hline $\begin{array}{l}\text { Freeze up (experience - mental block\|) on } \\
\text { important examinations. }\end{array}$ & 25 & 64 & 25 & 10 \\
\hline $\begin{array}{l}\text { During an important test I am so tense that my } \\
\text { stomach gets upset. }\end{array}$ & 31 & 56 & 28 & 9 \\
\hline $\begin{array}{l}\text { The thought of doing poorly interferes with my } \\
\text { concentration on tests. }\end{array}$ & 12 & 71 & 32 & 9 \\
\hline $\begin{array}{l}\text { The harder I work at taking a test, the more } \\
\text { confused I get. }\end{array}$ & 30 & 59 & 27 & 8 \\
\hline During tests I feel very tense & 19 & 67 & 32 & 6 \\
\hline
\end{tabular}


Based on table 4.1 reveals that the level of test anxiety among of foundation students in Islamic University Malaysia. From the analysis, the scale number four have the highest percentage $(33.9 \%)$ among the others which can show that most of the students wish examinations do not bother them so much. Meanwhile, the scales number one, two and three there are have the lowest percentage, which is $(10.5 \%, 25 \%, 29.8 \%)$ respectively.

In brief, the foundation students among college of economic in International Islamic University Malaysia have high level of test anxiety based on the result shown the scale number four.

\subsection{Academic Self-Regulated}

Table 4.2. Level of academic self-regulated among foundation students in the Kulliyyah of Economic.

\begin{tabular}{|c|c|c|c|c|}
\hline Item & 1 & 2 & 3 & 4 \\
\hline Write the information that I need to remember & 4 & 5 & 57 & 58 \\
\hline $\begin{array}{l}\text { I check my progress by reviewing my past } \\
\text { performance }\end{array}$ & 2 & 24 & 53 & 45 \\
\hline $\begin{array}{l}\text { If I am having a difficulty, I seek assistance } \\
\text { from an expert }\end{array}$ & 3 & 16 & 61 & 44 \\
\hline I summarize what I have read & 3 & 14 & 64 & 43 \\
\hline I keep my past notes. & 2 & 16 & 63 & 43 \\
\hline I visualize words in my mind to recall terms & 1 & 15 & 66 & 42 \\
\hline $\begin{array}{l}\text { I seek others 'opinion on the things I need to } \\
\text { change in my work when in doubt. }\end{array}$ & 2 & 22 & 58 & 42 \\
\hline I outline the topics that I need to study & 4 & 8 & 71 & 41 \\
\hline I use my own words in writing my notes. & 4 & 14 & 66 & 40 \\
\hline $\begin{array}{l}\text { I improve my work by considering relevant } \\
\text { feedback I receive. }\end{array}$ & 1 & 19 & 64 & 40 \\
\hline $\begin{array}{l}\text { I ask a classmate about the homework that I } \\
\text { missed. }\end{array}$ & 2 & 16 & 67 & 39 \\
\hline I ask the help of friend to review my lessons. & 3 & 26 & 56 & 39 \\
\hline I make a list of the things I need to do & 7 & 27 & 52 & 38 \\
\hline $\begin{array}{l}\text { I am open to feedback in order to improve my } \\
\text { work. }\end{array}$ & 1 & 17 & 69 & 37 \\
\hline I focus myself in order to study. & 5 & 18 & 64 & 37 \\
\hline $\begin{array}{l}\text { I represent concepts with symbols such as } \\
\text { drawing so I can easily remember them. }\end{array}$ & 4 & 23 & 61 & 36 \\
\hline $\begin{array}{l}\text { I record (e.g. take notes) the lesson that I attend } \\
\text { to }\end{array}$ & 4 & 18 & 67 & 35 \\
\hline $\begin{array}{l}\text { I make sure to submit quality work despite other } \\
\text { activities. }\end{array}$ & 8 & 15 & 67 & 34 \\
\hline I make sure to submit good work on time. & 7 & 17 & 66 & 34 \\
\hline I find a place where I can study. & 5 & 22 & 64 & 33 \\
\hline $\begin{array}{l}\text { I check my homework to make sure that it is } \\
\text { done properly before submitting. }\end{array}$ & 10 & 18 & 63 & 33 \\
\hline I study whenever I can. & 8 & 25 & 58 & 33 \\
\hline I welcome feedback on my work & 2 & 18 & 72 & 32 \\
\hline I keep track of my accomplishments & 3 & 21 & 68 & 32 \\
\hline I organize the materials that I need to study. & 6 & 4 & 82 & 32 \\
\hline
\end{tabular}

\begin{tabular}{|c|c|c|c|c|}
\hline Item & 1 & 2 & 3 & 4 \\
\hline $\begin{array}{l}\text { I am aware of my progress when doing certain } \\
\text { activities }\end{array}$ & 4 & 20 & 69 & 31 \\
\hline I group similar information into a category & 2 & 16 & 76 & 30 \\
\hline $\begin{array}{l}\text { I summarize the topics that we take up (study) } \\
\text { in class }\end{array}$ & 3 & 24 & 67 & 30 \\
\hline I plan the things I have to do in the week & 9 & 24 & 61 & 30 \\
\hline $\begin{array}{l}\text { I evaluate my accomplishments at the end of } \\
\text { each study session }\end{array}$ & 6 & 26 & 62 & 30 \\
\hline $\begin{array}{l}\text { I ask for feedback on my performance from } \\
\text { someone whom I think is good at it }\end{array}$ & 3 & 20 & 71 & 30 \\
\hline $\begin{array}{l}\text { I listen attentively to people who comments on } \\
\text { my work }\end{array}$ & 3 & 19 & 72 & 30 \\
\hline $\begin{array}{l}\text { I make time for my schoolwork despite other } \\
\text { activities. }\end{array}$ & 5 & 21 & 68 & 30 \\
\hline I let others assess my work before submission. & 5 & 36 & 53 & 30 \\
\hline I draw figures to understand ideas better & 4 & 17 & 74 & 29 \\
\hline I read my notes aloud while studying & 7 & 32 & 56 & 29 \\
\hline $\begin{array}{l}\text { I use a variety of sources when doing } \\
\text { university-related task. }\end{array}$ & 1 & 21 & 73 & 29 \\
\hline $\begin{array}{l}\text { I make a schedule for the activities I need to } \\
\text { complete }\end{array}$ & 5 & 36 & 55 & 28 \\
\hline $\begin{array}{l}\text { I have in mind an end goal in every task that I } \\
\text { engage }\end{array}$ & 4 & 24 & 68 & 28 \\
\hline I share with my peers what I have learned. & 2 & 19 & 75 & 28 \\
\hline $\begin{array}{l}\text { I mark important concepts and information I } \\
\text { find in my reading. }\end{array}$ & 3 & 11 & 82 & 28 \\
\hline $\begin{array}{l}\text { I make sure to accomplish the things I need to } \\
\text { do each day }\end{array}$ & 2 & 26 & 69 & 27 \\
\hline $\begin{array}{l}\text { I keep track of myself if I am accomplishing my } \\
\text { goals }\end{array}$ & 6 & 22 & 69 & 27 \\
\hline $\begin{array}{l}\text { I construct questions from a topic and answer } \\
\text { them }\end{array}$ & 10 & 41 & 48 & 25 \\
\hline I make my own notes in class. & 3 & 27 & 69 & 25 \\
\hline I enjoy group work because of the cooperation. & 9 & 21 & 69 & 25 \\
\hline I compare my notes with that of my classmates. & 8 & 44 & 48 & 24 \\
\hline $\begin{array}{l}\text { I avoid any distractions while doing school } \\
\text { work. }\end{array}$ & 7 & 23 & 71 & 23 \\
\hline $\begin{array}{l}\text { I find a way to minimize distraction when I } \\
\text { study. }\end{array}$ & 10 & 27 & 64 & 23 \\
\hline $\begin{array}{l}\text { I make sample questions from a topic and } \\
\text { answer them }\end{array}$ & 8 & 43 & 52 & 20 \\
\hline $\begin{array}{l}\text { I continue studying on a topic even if it is not } \\
\text { required. }\end{array}$ & 6 & 41 & 57 & 20 \\
\hline $\begin{array}{l}\text { I anticipate the type of test questions to pace } \\
\text { myself in studying. }\end{array}$ & 1 & 21 & 82 & 20 \\
\hline $\begin{array}{l}\text { I use library resources to find the information } \\
\text { that I need }\end{array}$ & 7 & 48 & 51 & 18 \\
\hline $\begin{array}{l}\text { I am not easily distracted by the things around } \\
\text { me when I study. }\end{array}$ & 19 & 49 & 41 & 15 \\
\hline
\end{tabular}

Based on table 4.2 reveals the level of academic selfregulated among of foundation students in Islamic University Malaysia. From the analysis, the scale number four has the highest percentage (46.8\%) among the others that can show most of the students write the information that they need to remember. Meanwhile, the scales number one, two and three there are have the lowest percentage, which is $(3.2 \%, 4 \%$ and $46 \%$ ) respectively. 
In brief, the foundation students among college of economic in International Islamic University Malaysia have high level of academic self-regulated based on the result showed the scale number four.

\subsection{The Relationship Between Test Anxiety and Academic Self-Regulated Learning}

The relationships between independent variables and dependent variable are shown in Table (4.3)

Table 4.3. The relationships between independent variables and dependent variable are shown in.

\begin{tabular}{lllll}
\hline \multicolumn{2}{l}{ Model Summary } & & & \\
\hline Model & R & R Square & $\begin{array}{l}\text { Adjusted R } \\
\text { Square }\end{array}$ & $\begin{array}{l}\text { Std. Error of the } \\
\text { Estimate }\end{array}$ \\
\hline 1 & $.066^{\mathrm{a}}$ & .004 & -.004 & 10.64655 \\
\hline
\end{tabular}

a. Predictors: (Constant), academic self-regulated

b. Dependent Variable: test anxiety

Table (4.3) shows that self-regulated did not predict test anxiety at level of $\mathrm{p}>0.05$

\subsection{The Differences Between Genders}

Table 4.4. Shows the differences of Anxiety and self-regulated between male and female students.

\begin{tabular}{|c|c|c|c|c|c|}
\hline & Gender & $\mathbf{N}$ & Mean & $\begin{array}{l}\text { Std. } \\
\text { Deviation }\end{array}$ & $\begin{array}{l}\text { Std. Error } \\
\text { Mean }\end{array}$ \\
\hline \multirow{2}{*}{$\begin{array}{l}\text { Test } \\
\text { anxiety }\end{array}$} & Male & 63 & 48.5873 & 8.86937 & 1.11744 \\
\hline & Female & 61 & 47.1967 & 12.21450 & 1.56391 \\
\hline \multirow{2}{*}{$\begin{array}{l}\text { Academic } \\
\text { self- } \\
\text { regulated }\end{array}$} & Male & 63 & 155.7937 & 21.09209 & 2.65735 \\
\hline & Female & 61 & 168.4426 & 22.89507 & 2.93141 \\
\hline
\end{tabular}

Based on the result in table 4.4 we do not find big differences between males and females by the mean score in term of test anxiety. Meanwhile, the mean score of academic self-regulated among female more than male.

The main differences have been further confirmed through the t-test analysis as shown in table (4.5).

Table 4.5. Shows the t-test of Anxiety and self-regulated between male and female students.

\begin{tabular}{llllll}
\hline & $\begin{array}{l}\text { Levene's Test for } \\
\text { Equality of } \\
\text { Variances }\end{array}$ & t-test for Equality of Means \\
\cline { 2 - 6 } & F & Sig. & t & df & Sig. (2-tailed) \\
\hline Test anxiety & 3.07 & 0.082 & 0.727 & 122 & 0.469 \\
\hline $\begin{array}{l}\text { Academic self- } \\
\text { regulated }\end{array}$ & 0.004 & 0.952 & -3.201 & 122 & 0.002 \\
\hline
\end{tabular}

The results in table (4.5), showed that there is no significant difference between male and female students; $\mathrm{f}$ $(122)=3.07, t=0.727, p>0.05$ in their test anxiety. Thus, it shows that levels of test anxiety are similar across male and female students.
The results showed that there is a significant difference between male and female students; $\mathrm{f}(122)=0.004, \mathrm{t}=-3.201$, $\mathrm{p}<0.05$ in their academic self-regulated. Thus, it shows that levels of academic self-regulated are not similar across male and female students.

\section{Conclusion}

Due to the several limitations of the current research, researcher has recommended to the future researchers to select the samples from other undergraduate students from other college district or state can be used instead. In addition, future researches may use other methods such as interview and observation or both of them to get more reliable data; specifically, in assessing students' test anxiety and academic self-regulated learning. The current research revealed that most of the students had high level of test anxiety and academic self-regulated. There was no statistically significant difference between male and female in their test anxiety; $f$ $(122)=3.07, t=0.727, p>0.05$; also the result showed that there was a statistically significant difference between male and female in their academic self-regulated; $f(122)=0.004, t$ $=-3.201, \mathrm{p}<0.05$. Pearson's regression showed that self regulated did not predict test anxiety at level of $p>0.05$.

\section{References}

[1] Bembenutty, H., McKeachie, W. J, Karabenick, S. A., \& Lin, Y. (1998). The relationship between test anxiety and selfregulation on students 'motivation and learning. Paper presented at annual meeting of the American psychological society, May 1998.

[2] Cizek, G. J., \& Burg, S. S. (2006). Addressing test anxiety in a high-stakes environment. California: Corwin press, A SAGE publications company, Thousand Oaks.

[3] Charlotte Dignath-van Ewijk, \& Greetje van, d. W. (2012). What teachers think about self-regulated learning: Investigating teacher beliefs and teacher behavior of enhancing students' self-regulation. Education Research International.

[4] Chin, Cassady, J., \& Johnson, R. (2001). Cognitive test anxiety and academic performance. Contemporary Educational Psychology, 27, 270-295.

[5] Chapell, M. S., Blanding, B., Silverstein, M.E., Takahashi, M, Newman, B., Gubi, A., \& McCann, N. (2005). Test anxiety and academic performance in undergraduate and graduate students. Journal of Educational Psychology, 97, (2) 268-27.

[6] Creswell, J. W. (2008). Educational research: planning, conducting, and evaluating quantitative and qualitative research (3Ed). USA: Pearson Prentice Hall.

[7] Davies, D. (1986). Maximizing examination performance; a psychological approach. New York: Nichols Publishing Company.

[8] Di Maria, F., \& Di Nuovo, S. (1990). Gender differences in social and test anxiety. Personality and Individual Differences, $11(5), 525-530$. 
[9] Eubank, C. C. (1993). The relationship among test anxiety, academic achievement, and age in associate degree nursing students. ProQuest ILC.

[10] Everson, H. T., Millsap, R. E., \& Rodriguez, C. M. (1991). Isolating gender differences in test anxiety: a confirmatory analysis of the test anxiety inventory. Educational and Psychological Measurement, 51 (1), 243-251.

[11] Fiore, A. M. (2003). Gender differences in test anxiety. ProQuest ILC.

[12] Gay, L. R., \& Airisian, P. (2000). Educational Research: Competencies for analysis and application (6Ed). Upper Saddle River, NJ: Prentice-Hall International, Inc.

[13] Henrich, D. L., \& Spielberger, C. D. (1982). Anxiety and complex learning. In Krohne, H.W. \& Laux, L. (Eds). Achievement, stress, and anxiety. USA: Hemisphere Publishing Corporation.

[14] Jabir, M. A. (2009). Test anxiety among African students at the International Islamic University Malaysia. Unpublished master's thesis, International Islamic University Malaysia, Kuala Lumpur.

[15] Kesici, S., \& Erdoğan, A. (2009). Predicting college students 'mathematics anxiety by motivational beliefs and selfregulated learning strategies. College Student Journal, 43 (2), 631-642.

[16] Krejcie, R. V., \& Morgan, D. W. (1970). Determining sample size for research activities. Educational and Psychological Measurement, 30, 607-610.

[17] Liu, S. (2015). Effects of self-perceptions on self-learning among teacher education students. International Education Studies, 8(10), 63-71.

[18] Magno, C. (2011). Validating the Academic Self-Regulated Learning Scale with the Motivated Strategies for Learning Questionnaire (MSLQ) and Learning and Study Strategies Inventory (LASSI). The International Journal of Educational and Psychological Assessment, 7 (2), 56-73.

[19] Meunier, C., \& Rule, R. G. (1967). Anxiety, confidence, and conformity. Journal of Personality, 35, 498-504.

[20] Morris, L. W., Davis, M. A., \& Hutchings, C. H. (1981) Cognitive and Emotional Components of Anxiety: Literature Review and a Revised Worry-Emotionality Scale. Journal of Educational Psychology, 73 (4), 541-555.

[21] Mousavi, Ms., Haghshenas, H., \& Alishahi, M.J. (2008). Effect of gender, school performance and school type on test anxiety among Iranian adolescents. Iranian Red Crescent Medical Journal, 10(1): 4-7.

[22] Mohamed Amil, M. (2000). Self-efficacy and academic performance in Economics in the junior college. M. Ed Thesis. Nanyang Technological University.

[23] Oude, G. B., Sleegers, P. J., \& van Veen, K. (2015). Promoting VET teachers' individual and social learning activities: The empowering and purposeful role of transformational leadership, interdependence, and self-efficacy. Empirical Research in Vocational Education and Training, 7(1), 1-20.

[24] Pecoraro, A. (2006). Cognitive behavioral, psychoanalytic, and psychophysiological factors associated with high test anxiety among college students. ProQuestILC.
[25] Pekrun, R., Goetz, T., Titz, W., \& Perry, R.P. (2002). Academic emotions in students 'self-regulated learning and achievement: a program of qualitative and quantitative research. Educational Psychologist, 37(2), 91-105.

[26] Putwain, D. W. (2008). Test anxiety and GCSE performance: the effect of gender and socio-economic background. Educational Psychology in Practice, 24 (4), 319-334.

[27] Rana, R. A., \& Mahmood, N. (2010). The relationship between test anxiety and academic achievement. Bulletin of Education and Research, 32 (2), 63-74.

[28] Wirth, J., \& Leutner, D. (2008). Self-regulated learning as a competence; implications of theoretical models for assessment methods. Journal of Psychology, 216 (2), 102-110.

[29] Zimmerman, B.J. (1986). Becoming a self-regulated learner: which are the key subprocesses? Contemporary Educational Psychology, 11, 307-313.

[30] Zimmerman, B. J. (1990). Self-regulated learning and academic achievement: An overview. Educational Psychologist, 25 (1), 3-17.

[31] Zimmerman, B. J. \& Martinez-Pons, M. (1988). Construct validation of a strategy model of students self-regulated learning. Journal of Educational Psychology, 80 (3), 284-290.

[32] Zimmerman, B. J., \& Kitsantas, A. (2005). Homework practices and academic achievement: the mediating role of self-efficacy and perceived responsibility beliefs. Contemporary Educational Psychology 30, 397-417.

[33] Razazadeh, M., \& Tavakoli, M. (2009). Investigating the Relationship among test anxiety, gender, academic achievement and years of study: acase of Iranian EFL university students. English Language Teaching, 2 (4), 68-74.

[34] Rocklin, T., \& Thompson, J. M. (1985). Interactive effects of test anxiety, test difficulty, and feedback. Journal of Educational Psychology, 77 (3), 368-372.

[35] Schunk, D. H. (1991). Self-efficacy and academic motivation. Educational Psychologist, 26 (3 and 4), 207-231.

[36] Song, Y., Yun, S. Y., Kim, S., Ahn, E., \& Jung, M. S. (2015). Role of self-directed learning in communication competence and selfefficacy. Journal of Nursing Education, 54(10), 559-564.

[37] Spruce, R., \& Bol, L. (2015). Teacher beliefs, knowledge, and practice of self-regulated learning. Metacognition and Learning, 10(2), 245-277.

[38] Tantrarungroj, P., \& Suwannatthachote, P. (2012). Enhancing pre-service teacher's self-efficacy and technological pedagogical content knowledge in designing digital media with self-regulated learning instructional support in online project-based learning. Creative Education, 3, 77-81.

[39] Thobias, S. 1985. Test Anxiety: Interference, defective skills and cognitive capacity. Educational Psychologist, 20 (3), 135-142.

[40] Venzile-Tamsen, C. M. (1998). Factors underlying cognitive strategy use. Paper presented at the annual meeting of the Eastern Educational Research Association (Tampa, FL, February 24-27).

[41] Wang, C., Shannon, D. M., \& Ross, M. E. (2013). Students' characteristics, self-regulated learning, technology selfefficacy, and course outcomes in online learning. Distance Education, 34(3), 302-323. 
[42] Weinstein, C. E., \& Mayer, R. E. (1986). The teaching of learning strategies. In M. C.
[43] Wittrock (Ed.), Handbook of research on teaching (pp. 315327). New York: Macmillan. 